\title{
Millennial Expectations about the Desire to Stay in the Workplace and Factors that Influence it
}

\author{
Anita Maharani, Hendra Gunawan, Jonathan David Tirta Wijaya
}

\begin{abstract}
Employee retention among millennials has been garnering attention of many organizations especially the growing numbers of this generation in the workforce. Interestingly, this generation is observed to have unique characteristics that are different from the other generations, which one of them includes their habit of frequently switching jobs. This unique habit of them poses a threat to the organizations as there are costs involved during recruitment, hiring and training. Some identified factors that influence their retention are namely: 1) work-life balance, 2) awards, 3) opportunity for personal development, 4) career achievement and 5) company's concern on the employee's ability. This research aims to examine millennials' expectation surrounding their current working activity and the degree of preferences among the five factors mentioned. Results of our study shows that in general, all above mentioned factors are present in the organization where they are working at. Whereas for their preferences, opportunity for personal development ranks first followed by work-life balance, career achievements, awards and lastly, the company's concern on the employee's ability.

Keywords: Millenials, Expectations, Stay, Work.
\end{abstract}

\section{INTRODUCTION}

$\mathrm{E}_{\text {mployee retention is an important thing to be managed }}$ by the organization. Organizations must have the ability to maintain their talents, and that in this way keep the talent who has the performance that contributes to the organization to stay in the company. There is a trend that shows that companies have obstacles in managing their talent retention, as stated in the study of the Chartered Institute of Personnel Development (CIPD) that $78 \%$ of the sample companies they use have obstacles in how effective strategies are to retain their employees. What impact will be received by the company if it fails to maintain its employees, it will get a condition where the company's performance will experience a negative impact, namely costs. Costs are considered to be a negative impact of employee turnover, because unwittingly to acquire talent, the company actually has invested in recruitment, hiring, training and overtime costs (if any) and does not necessarily have a positive contribution to the

Revised Manuscript Received on March 13, 2020.

* Correspondence Author

Anita Maharani*, Business Management Program - BINUS Business School Master Program, Bina Nusantara University, Jakarta, Indonesia. Email: anita.maharani@binus.ac.id; anita.maharani@binus.edu.

Hendra Gunawan, Business Management Program - BINUS Business School Master Program, Bina Nusantara University, Jakarta, Indonesia. Email: hendra.gunawan004@binus.ac.id

Jonathan David Tirta Wijaya, Business Management Program BINUS Business School Master Program, Bina Nusantara University, Jakarta, Indonesia. Email: jonathan.wijaya002@binus.ac.id

(c) The Authors. Published by Blue Eyes Intelligence Engineering and Sciences Publication (BEIESP). This is an open access article under the CC BY-NC-ND license (http://creativecommons.org/licenses/by-nc-nd/4.0/) company.

Although it is known that turnover will push on something negative, In Yazinski (2009) [1] mentioned several reasons for the reason talents leave the organization, which among others is a mismatch between expectations about what is imagined from work and those obtained at work, then do not feel there are adjustments between work life and personal life, there is no assistance from parties who according to employees can provide feedback and guidance in completing work. Whereas, on the other hand, Myatt (2012) [2] mentions the reasons given by the best talents when deciding to withdraw from their work, among others, 1) the best talents will retreat when they feel the company is unable to fulfill the desires built, 2) feel that the company is not again providing challenges, 3) feeling that creativity is no longer practicable, 4) feeling unable to develop skills so that they have added value 5) feeling failed to issue opinions, 6) feeling unnoticed, 7) feeling not seeing the company's commitment to talent. Working and producing value is everyone's dream. To be able to work, the abilities a person has determines the extent to which values can be obtained. This underlies the premise that ideally someone will make every effort so that their energy and talents can contribute to the company. Then, on the other hand there are also studios about generations that provide more for a variety of previous generations of work, and found a generation that is more work-oriented than the previous generation (Pyoria, Ojala, Saari, Jarvinen, 2017) [3].

On January 6 - 12, 2019, trends.google.com noted that in United States there was a high frequency of searching keywords: millennials and occupational burnout syndrome. This finding was quite interesting, where California stands out to be the location. The related queries was "how millennials became the burnout generation". What was actually happened at that time? Why would this query showed at that particular time?, was there any specific event at that time?. Peterson (2019) [4] wrote an article, and shows through her writing about interesting keywords related with her intentions on writing that article. She describe millennials as those who complain, about 1) how other millennials labelled them with a bad reputation, 2) millennials internalized the idea of working all the time because of economy reasons such as less saving, and debt trap.

Research for the past 5 years shows that compensation and benefits were common factors that stimulate intention to stay (Johanim, Yean, Adnan, Yahya, Yahya, Nassruddin, 2012 [5]; Bryant and Allen, 2013 [6]; Parashakti, Nashar, and Usliawati, 2017 [7]; Mabaso and Diamini, 2017) [8].

Published By:

Blue Eyes Intelligence Engineering

\& Sciences Publication

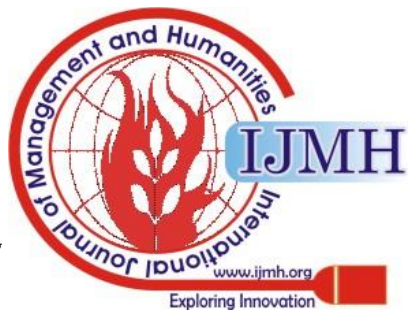


But will this become the only factors?, apparently not, affective commitment, normative commitment and goal clarity were found as also factors that promoting someone's intention to stay or not to stay in the organization (Ghosh, Satyawadi, Joshi, and Shadman, 2013 [9]; Sow, 2015 [10]; Suharno, Setiawan, Setyadi, Elmi, 2017) [11]. Therefore possible factors may stimulate people on staying in their workplace, both material and immaterial rewards. But will this can be generalize if it relates with demographic factor? Nowadays, organizations face demographics at work. It is common these days, that workplace consists of more than one generation, or in current trends nowadays, according to Shah (2011) [12] that it is possible to see five generations involve in one workplace. But why demographics matter? Since it always been something that consider to be generalize by organizations without looking further on specific situations. Like in US organizations, that face phenomena where they fail to retain generation called millennials not more than three years (Simmons, 2016) [13]. Millennials, needs customize strategies that been thought by organizations work for previous generations (Thompson, 2011) [14]. Purposes of study will be: 1 ) What are expected by millennials according to their current working activity? 2) Which of the following factors that mostly preferable by millennials?

\section{METHOD}

The method used in this study is quantitative, designed descriptively. Samples in this study are 120 respondents, which were obtained randomly and voluntarily by respondents. The method of collecting this data is by distributing surveys through social media networks owned by researchers totaling more than 300 people. The closed question instrument used to measure millennial desires to remain in work, using Likert Scale, and questions includes, 1) At present, companies / organizations are trying to reward according to the performance that I have shown, 2) I consider there are opportunities for self-development while working here, 3 ) I see that there is a business company / organization providing support for a balance between work and personal life, 4) I see there is a company effort to find out my talents, desires or expertise, 5) I get the achievements that I expect while in the company / this organization, 6) I believe that I will be in this company for a long time. In addition to closed question instruments, there are also open question instruments, as follows, 1) What things will make you not survive in the current workplace ?, 2) What things will make you stay in the workplace when this?. Questions were developed based on exploration purpose. The processing of the collected data is then analyzed using statistical applications, using descriptive statistical methods, including the mean.

\section{RESULT AND DISCUSSION}

The respondents of this study consisted of $40 \%$ were men and $60 \%$ were women. These respondents work in telecommunications companies (40\%), banks (20\%), media companies (10\%), and the rest in their own businesses (20\%). What is interesting in the dissemination of this data is the involvement of respondents who come from their own businesses, volunteering to become respondents, and of course the results of this study will provide an interesting picture of the factors that make someone want to stay in their work environment.

Based on the results of data processing, the results are obtained and can be sorted by rank, from the highest (lowest number) to the lowest (last number) related to the preference of the factors that make millennial want to survive in their workplace. As follows: 1) the highest ranking is the opportunity for personal development, 2) the balance of work and personal life, 3) achievement in career, 4) awards received at work and 5) the company's concern about the ability of employees.

This survey has a scale of $1-4$, where 1 represents strongly disagree, up to 4 representing strongly agree. From the results of data collection, all instrument items were responded to, and the average answer was 2.8 or close to agree. In other words, if explained on a per item basis, as follows:

1. In general, respondents feel that the company / organization where they work is trying to give awards in accordance with the performance indicated by respondents.

2. In general, respondents feel that there are opportunities for personal development while working in the company.

3. In general, respondents see a company / organization's business providing support for a balance between work and personal life.

4. In general, respondents see the company's efforts to find out the talents, desires or expertise possessed by respondents.

5. In general, respondents obtain the expected achievements while in the company / organization where they work.

The results above actually indicate a phenomenon that respondents still do not really agree with the items given. This certainly needs to be explored more deeply, first of course related to whether the company has accommodated the things given in the measurement items, especially regarding appreciation, self-development, support for work and life balance, the company's understanding of the ability of employees or in this case is how far the company can empathize with company knowledge. However, when respondents were asked about the possibility that they would last a long time at their place of work, through the item "I believe that I will be in this company for a long time" in general the value obtained is 2.2 .

Then, how previous research or even previous findings about known factors can influence an employee to feel at home in the company. According to several sources, there are reasons why employees stay at their workplace, but interestingly one of many reasons stated that if employees feel comfortable (in many options). Therefore it is reasonable if many researchers works in instrument development on intention to stay instrument, Mohanachandran and Govindarajo (2014) [15] are one of many examples, they seek reasons on why employees stay in their workplace by looking at absenteeism, attrition, organizational member's intention to leave and retention.

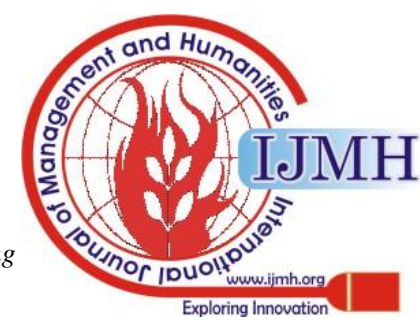


Mohanachandran et al (2014) [15] develop their instrument after qualitative approach, through content analysis, individual interview with several organization member, focus group discussion and also delphi technique.

Bush (2018) [16] wrote on several things that has been done by companies in order to keep their employees stay in their office, includes 229,000 surveys of leading companies, if employer gives a standout, then employees would likely to stay rather than they are given an extra money to get a job done, next would be about culture, that plays an important role in making employees stay longer in an office. Moreover, despite their advantages, the best working environments offer societies based on trust. Their kin realize they can depend on companions and administrators for help and that their work will be made a decision on its benefits alone.

\section{CONCLUSION AND RECOMMENDATION}

Based on the explanation above, it can be concluded that there are a number of factors that influence an employee to remain in the company, especially in terms of employee expectations regarding rewards and how the company sees the achievements given by individuals. This research shows that there is an opportunity to research further about what are the factors that make a person still want to live in his workplace, especially can be done with interviews or other data mining methods that allow exploration of information from respondents. Opportunities to compare between generations are also interesting to do, because there could be possible differences in factors that influence employees to remain in the company.

\section{REFERENCES}

1. Yazinski, S.K. (2009 03 08). Strategies for Retaining Employees and Minimizing Turnover. Compliance Tools for HR Professionals. Retrieved from https://hr.blr.com/whitepapers/Staffing-Training/Employee-Turnover/ Strategies-for-Retaining-Employees-and-Minimizing

2. Myatt, M. (19 December 2012). The \#1 reason leadership development fails Forbes. Retrieved from http://www.forbes.com/sites/mikemyatt/2012/12/19/the-1-reason-lead ership-development-fails/

3. Pyöriä, P., Ojala, S., Saari, T., \& Järvinen, K.-M. (2017). The Millennial Generation: A New Breed of Labour? SAGE Open. https://doi.org/10.1177/2158244017697158.

4. Peterson, Anne Helen. (2019). How Millenials Became the Burnout Generation. Source: https://www.buzzfeednews.com/article/annehelenpetersen/millennials -burnout-generation-debt-work

5. Johanim, Johari \& Fee Yean, Tan \& Adnan, Zurina \& Yahya, Khulida \& Yahya, Devi \& Nassruddin, Mohamad. (2012). Promoting Employee Intention to Stay: Do Human Resource Management Practices Matter?. International Journal of Economics and Management. 6. 396-416.

6. Bryant, Phil \& Allen, David. (2013). Compensation, Benefits and Employee Turnover HR Strategies for Retaining Top Talent. Compensation \& Benefits Review. 45. 171-175. 10.1177/0886368713494342.

7. $\quad$ Parashakti, Ryani Dhyan; Nashar, Muhammad; Usliawati, Desi. 2017. The Effect of Compensation and Organization Commitment Towards Turnover Intention. Case Study in ILC (International Language Center) Jakarta. Advances in Intelligent Systems Research, International Conference of Organizational Innovation, Volume 13, Atlantis Press.

8. Mabaso, Alvin Mzwenhlanhla \& Dlamini , Bongani Innocent, (2017). Impact of Compensation and Benefits on Job Satisfaction. Research Journal of Business Management, 11: 80-90. DOI: $10.3923 /$ rjbm.2017.80.90 URL: https://scialert.net/abstract/?do i=rjbm.2017.80.90.
9. Ghosh, Piyali \& Satyawadi, Rachita \& Prasad Joshi, Jagdamba \& Shadman, Mohd. (2013). Who stays with you? Factors predicting employees' intention to stay. International Journal of Organizational Analysis. 21. 10.1108/IJOA-Sep-2011-0511.

10. Sow, Mouhamadou Thile. 2015. Relationtship Between Organizational Commitment and Turnover Intentions Among Healthcare Internal Auditors. Dissertation. Walden University, College of Management and Technology.

11. Suharno, Suharno \& Setiawan, K \& , Setyadi \& Elmi, F. (2017). THE EFFECT OF ORGANIZATIONAL COMMITMENT TOWARD TURNOVER INTENTION AT NARADA SCHOOL, INDONESIA. Russian Journal of Agricultural and Socio-Economic Sciences. 62 55-66. 10.18551/rjoas.2017-02.07.

12. Shah, Rawn. 2011. Working With Five Generations In the Workplace https://www.forbes.com/sites/rawnshah/2011/04/20/working-with-fiv e-generations-in-the-workplace/\#1f427ed53e7a.

13. Simmons, Alphonso M., 2016. Exploring Millenial Retention Strategies and Methods in the Workplace. Dissertation. Walden University, College of Management and Technology.

14. Thompson, Nicholas W. 2011. Managing the Millenials: Employee Retention Strategies for Generation Y. Theses. CMC Senior Theses. CMC Student Scholarship. Claremont McKenna College.

15. Mohanachandran, Dileep \& S Govindarajo, Normala. (2014). Instrument Development " Intention to Stay Instrument " (ISI). Asian Social Science. 10.

16. Bush, Michael. (2017). 2 Things the Best Companies to do to Keep Their Employees Happy. Source: https://www.cnbc.com/2017/06/01/2-things-the-best-companies-do-to -keep-their-employees-happy.html.

\section{AUTHORS PROFILE}

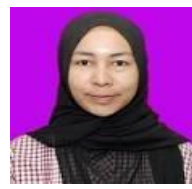

Currently in Binus Business School as fulltime faculty member

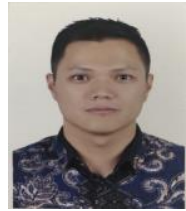

Graduated with Bachelor degree from Sekolah Tinggi Ilmu Ekonomi Informasi Teknologi dan Bisnis Medan - Indonesia majoring in Management and Information Technology. Pursuing Master degree in Bina Nusantara University Jakarta - Indonesia Majoring in Business Management

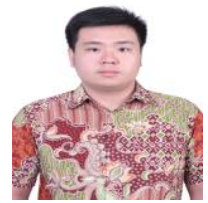

Graduated with Bachelor degree from Ciputra University Surabaya majoring in International Business Management. Pursuing Master degree in Bina Nusantara University Jakarta - Indonesia Majoring in Business Management

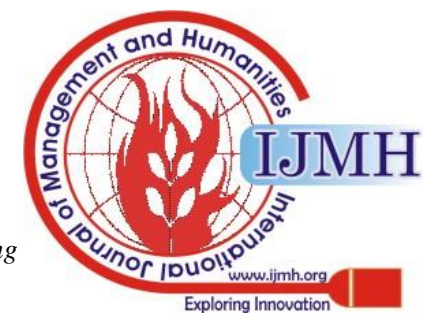

